\title{
Pengaruh Self Efficacy dan Motivasi Belajar terhadap Hasil Belajar Matematika Siswa MTs Al-Khairiyah Mampang Prapatan di Masa Pandemi COVID-19
}

\author{
Dewi Purnama Sari ${ }^{1 *}$, Yana $^{2}$, Ayu Wulandari ${ }^{3}$ \\ ${ }^{1}$ Program Studi Matematika, Universitas Pamulang, Indonesia \\ ${ }^{2}$ Pendidikan Matematika, SPs Universitas Muhammadiyah Prof. DR. HAMKA, Indonesia \\ ${ }^{3}$ Pendidikan Matematika, STKIP Kusuma Negara, Indonesia \\ *dosen01569@unpam.ac.id
}

\begin{abstract}
Abstrak
Pandemi Coronavirus disease 2019 (COVID-19) telah mengubah semua bidang, salah satunya sistem di bidang pendidikan. Guru dan siswa dituntut untuk belajar dari rumah melalui pembelajaran online hal ini tentunya dapat berpengaruh terhadap psikologi siswa khusunya dalam belajar. Penelitian ini dilatarbelakangi banyaknya keluhan siswa dalam mengerjakan tugas-tugas pelajaran matematika sementara mereka memiliki keterbatasan dalam belajar. Tujuan penelitian ini dilakukan untuk mengetahui pengaruh self efficacy dan motivasi dalam belajar siswa selama pembelajaran online terhadap hasil belajar matematika. Responden sebanyak 113 siswa kelas IX di MTs Al-Khairiyah Mampang Prapatan tahun ajaran 2020/2021 pada bulan Oktober sampai Desember 2020. Metode dalam penelitian menggunakan metode survey dengan teknik pengumpulan data yang yaitu melalui hasil angket self efficacy, angket motivasi belajar dan dokumentasi hasil belajar matematika siswa pada Penilaian Akhir Semester (PAS) kelas IX tahun ajaran 2020/2021. Analisis data yang digunakan adalah analisis statistik deskriptif dan statistik inferensial. Dari hasil penelitian menunjukan bahwa: (1) self efficacy berpengaruh positif terhadap hasil belajar matematika siswa, (2) motivasi dalam belajar berpengaruh positif terhadap hasil belajar matematika siswa dan (3) self efficacy berpengaruh positif terhadap motivasi belajar siswa.
\end{abstract}

Kata kunci: hasil belajar matematika, motivasi belajar, self efficacy.

Identitas Artikel:

Sari, D. P., Yana, Y., \& Wulandari, A. (2021). Pengaruh Self Efficacy dan Motivasi Belajar terhadap Hasil Belajar Matematika Siswa MTs Al-Khairiyah Mampang Prapatan di Masa Pandemi COVID-19. Jurnal Ilmu Pendidikan (JIP) STKIP Kusuma Negara, 13(1), 1-11.

\section{PENDAHULUAN}

Akibat virus corona banyak negara mewajibkan menutup sementara pembelajaran langsung di sekolah guna menghentikan penyebaran virus, yang merupakan tantangan bagi 370 juta siswa diseluruh dunia (UNESCO, 2020). Semua pihak dari pemerintah, penyelenggara pendidikan, guru, siswa maupun orang tua saling bekerjasama demi kelancaran pembelajaran saat pandemi. Secara khusus COVID19 dapat mengancam kesehatan siswa, menyebabkan kecemasan dan depresi, sehingga dapat mempengauhi keterlibatan belajar siswa di rumah (Li dkk., 2020). Emosi negatif seperti depresi dapat mempengaruhi memori dan kemajuan akademik siswa (Kizilbash dkk., 2002). Keterlibatan dan interaksi antara guru dan 
siswa selama pembelajaran online sangat penting bagi siswa dalam membangun pemahaman tentang pengetahuan baru.

Tahun 1977, Bandura (1999) mulai merancang self efficacy yang dapat mempengaruhi serta memodifikasi tingkah laku manusia. Dengan self efficacy seseorang dapat mengerjakan tugas yang diatur secara efektif. Berkaitan dengan teori self efficacy menekankan tindakan maupun kesuksesan seseorang tergantung seberapa dalam pemikiran dan tugas yang diberikan mampu diinteraksikan dengan maksimal. Individu dengan self efficacy rendah mempunyai pemikiran negatif serta menganggap kewajiban tugas sebagai beban bukan sebuah tantangan sehingga akan menetapkan tujuan yang rendah untuk diri mereka sendiri (Yusuf, 2011). Sehingga self efficacy perlu dimiliki dalam proses pembelajaran terutama saat pandemic COVID-19, siswa dituntun untuk belajar lebih mandiri dibandingkan sebelum pembelajaran online.

Selain self efficacy, motivasi juga dianggap sebagai perantara yang berperan dalam menghasilkan minat dalam aktivitas sehingga meningkatkan kinerja yang lebih besar dalam belajar Schunk (dalam Tseng \& Tsai, 2010). Seorang siswa dengan adanya motivasi tinggi dalam belajar akan cenderung aktif dan berusaha terlibat dalam kegiatan belajar tersebut (dalam Wigfield dkk., 2011). Motivasi sangat berkaitan dengan prestasi yang dicapai dalam akademik (Singh dkk., 2002). Ketika seseorang memiliki motivasi yang baik maka dalam mengikuti proses pembelajaran dilakukan dengan semaksimal mungkin. Hal ini motivasi dalam belajar sesuatu yang penting untuk diperhatikan seorang pendidik serta orang tua, karena motivasi maupun pembelajaran saling berhubungan satu sama lain.

Observasi awal dilakukan terhadap salah satu MTs di Jakarta, diperoleh bahwa selama pembelajaran online siswa cenderung kurang aktif. Diketahui dari aktifitas pertemuan tatap muka secara online, pengumpulan tugas yang terlambat, bahkan tidak sedikit siswa yang tidak mengumpulkan tugas. Banyak faktor yang mempengaruhi itu semua, dugaan awal adalah siswa tidak memahami materi yang dipelajari, maupun kendala lain terkait jaringan internet (Hendrastomo, 2008). Dikuatkan dengan hasil wawancara terhadap beberapa siswa yang sering terlambat dalam mengumpulkan tugas, mereka beralasan belum memahami materi dengan baik, sehingga merasa putus asa dalam menyelesaikan tugas-tugas yang diberikan tanpa ada keinginan bertanya kepada guru maupun teman.

Melalui proses pembelajaran, harapan yang terbesar adalah siswa menjadi seorang pribadi yang mempunyai kualitas dalam menguasai ilmu pengetahuan dan teknologi serta akhlak. Hasil belajar salah satu out put yang dapat diamati dari proses belajar karena penting dalam proses pendidikan. Nilai biasanya menyatakan hasil dari proses pembelajaran yang dapat mengukur kognitif (Tambunan, 2018). Sehingga prestasi bisa kita artikan sebagai kemampuan maupun penguasaan siswa terhadap materi yang dipelajari.

Dari hasil penelitian Xiantang Yang dan kawan-kawan memberikan salah satu kesimpulan bahwa dalam proses pembelajaran jarak jauh, keyakinan diri adalah penentu yang kuat dan langsung dari keterlibatan belajar siswa dalam mempraktikan aplikasi QODE (Yang dkk., 2020). Sementara Ning (2020) dalam jurnal hasil penelitianya di Shanghai, China yang meneliti tentang disiplin, motivasi dan prestasi di pembelajaran matematika mendapati bahwa motivasi baik dari dalam maupun luar individu mempengaruhi prestasi daam pembelajaran 
matematika. Penelitian terkait self efficacy dan motivasi sudah pernah dilakukan dengan kesimpulan bahwa keyakinan diri dan motivasi tidak serta merta mempengaruhi tinggi atau rendahnya hasil belajar (Wahyuningtyas \& Febrianingsih, 2018). Seorang siswa jika keyakinan diri tinggi maka berusaha memotivasi dirinya dalam belajar. Menyelesaikan tugas yang sudah menjadi kewajibanya sehingga berusaha mencari alternatif dalam memecahkan persoalan yang dihadapi demi keberhasilan dalam belajar. Hal ini akan berdampak terhadap hasil pembelajaran yang dilakukan. Sehingga penelitian dilakukan untuk mengidentifikasi besarnya pengaruh self efficacy maupun motivasi belajar terhadap hasil pembelajaran matematika siswa di masa pandemi COVID-19.

\section{Self Efficacy}

Self efficacy merupakan kepercayaan diri yang dimiliki individu akan kemampuanya untuk berhasil dalam melakukan suatu kegiatan (Locke, 1997). Di dalam belajar tentunya seorang siswa hendaknya memiliki rasa kepercayaan diri, sebab dengan sikap tersebut dapat menambah daya dorong yang kuat untuk mengikuti proses belajar. Pantang menyerah adalah efek dari percaya diri. Niu (2010) menyebutkan self efficacy adalah hasil dari interaksi lingkungan eksternal dengan mekanisme penyesuaian diri serta kemampuan personal dalam diri individu mengenai pengalaman maupun pendidikan yang dilaluinya. Self efficacy memang tidak hadir tanpa sebuah pengalaman, sehingga seseorang akan memiliki Self efficacy jika seringnya berinteraksi dengan lingkungan dan pengalaman yang dilaluinya.

Self efficacy adalah harapan-keyakinan mengenai seberapa besar individu sanggup dan mampu melakukan suatu perilaku dalam kondisi tertentu (Friedman, 2003). Sehingga self efficacy sangat berhubungan dengan kepercayaan diri dan keyakinan terhadap suatu kemampuan. Keyakinan seseorang untuk menyelesaikan tugas-tugas yang diberikan sampai berhasil dengan baik. Santrock (2009) berpendapat bahwa Self efficacy diartikan sebagai percaya diri seseorang terhadap kemampuanya dalam menguasai dan mengkondisikan situasi dan menghasilkan sesuatu yang dapat menguntungkan. Dengan adanya Self efficacy maka seseorang dapat mencari jalan keluar dari setiap permasalahan. Karena situasi yang sedang dihadapi dapat dikuasai sehingga ide-ide akan muncul dengan sendirinya. Hal tersebut dapat menguntungkan bagi seseorang yang mempunyai keyakinan diri.

Dimensi Self efficacy terbagi ke dalam 3 yaitu dimensi level, dimensi generality dan dimensi strength. Beberapa indikator efikasi diri berdasarkan dimensi tersebut yaitu: (1) keyakinan diri yang menyelesaikan tugas-tugas tertentu, (2) keyakinan diri untuk menimbulkan memotivasi dalam diri sehingga dapat melakukan tindakan dalam menyelesaikan tugas atau permasalahan, (3) keyakinan dirinya untuk berusaha keras, ulet, gigih maupun tekun, (4) keyakinan kuat dalam menghadapi hambatan, tantangan dan kesulitan, (5) keyakinan dalam menyelesaikan tugas-tugas yang luas dan sempit (Yunianti, 2016).

\section{Motivasi Belajar}

Asal kata motivasi yaitu movere yang mempunyai arti menggerakan. Dorongan untuk belajar dapat timbul dari dalam individu baik secara sadar maupun tidak disadari. Dimyati \& Mudjiono (1994) berpendapat bahwa motivasi adalah dorongan dari mental sehingg akan mengarahkan maupun menggerakan suatu 
tingkah laku manusia dalam melakukan sesuatu termasuk dalam hal belajar. Sehingga motivasi dapat dimaknai sebagai alasan seseorang untuk melakukan perbuatan atau perilaku untuk menggapai suatu tujuan. Intelegensi dan bakat merupakan motivasi yang lahir dalam diri individu yang menjadi bawaan masingmasing (Hapsari, 2005). Sementara menurut Alderfer (dalam Nashr, 2004) menjelaskan motivasi dalam belajar merupakan suatu kecondongan atau kecenderungan diri siswa untuk melakukan seluruh kegiatan dalam pembelajaran yang dapat ditimbulkan dari hasrat dalam mencapai sebuah keberhasilan dan prestasi maupun hasil dalam belajar yang maksimal. Dengan kata lain timbulnya motivasi dikarenakan adanya keinginan untuk menggapai prestasi maupun hasil belajar sebaik mungkin, sehingga dapat mempengaruhi pola dalam mengikuti setiap proses belajar.

Sardiman (2000) menjelaskan motivasi berkaitan dalam pembelajaran yaitu faktor dari psikis yang sifatnya non intelektual sehingga dapat menambah gairah, rasa senang dan semangat dalam mengikuti proses pembelajaran. Chernis \& Goleman (dalam Sundari, 2017) menjelaskan 6 aspek dalam motivasi belajar yaitu: (1) Senang dan menikmati dalam belajar, (2) Berorientasi untuk menguasai materi pelajaran, (3) Hasrat ingin tahu yang tinggi, (4) Keuletan dalam menyelesaikan dan mengerjakan tugas, (6) keaktifan dan ikut serta maksimal dalam tugas, (7) Berorientasi kepada tugas-tugas. Dengan 6 aspek tersebut maka siswa akan lebih tertantang dalam menyelesaikan semua tugas yang sifatnya lebih sulit dan rumit.

\section{Hasil Belajar Matematika}

Belajar diartikan proses untuk perubahan tingkah laku menjadi lebih baik, sementara hasil belajar merupakan hasil dari sebuah proses perubahan dalam tingkah laku tersebut. Sehingga proses dalam belajar tentunya yang diharapkan yaitu hasil dimana bisa diperoleh baik secara langsung atau tidak langsung. Sementara menurut Dimyati \& Mudjiono (1994), hasil belajar adalah puncak dari sebuah proses pembelajaran. Hasil dari belajar bisa dilihat dari dua sisi yaitu sisi siswa adalah berakhirnya puncak pada proses pembelajaran. Sementara sisi guru bahwa tindakan mengajar diselesikan dengan proses mengevaluasi hasil pembelajaran.

Menurut Gagne (dalam Suprihatiningrum, 2013), hasil belajar terdiri dari 5 yaitu: (1) Informasi bersifat verbal, (2) Kemampuan intelektual, (3) Strategi mengenai kognitif, (4) Keterampilan atau kemampuan motorik, (5) Sikap dan perilaku. Itu semua merupakan komponen yang dapat dilihat dari proses perubahan sikap maupun tingkah laku yang merupakan hasil dalam proses pembelajaran yang dilakukan. Sementara Sudjana (2005) menjelaskan mengenai hasil belajar hakikatnya merupakan proses perubahan tingkah laku. Banyak faktor yang mempengaruhi perubahan tingkah laku pada siswa, baik timbul dari dalam diri atau timbul dari faktor luar.

Hasil belajar merupakan output dari suatu sistem pemprosesaan berbagai input yang dapat berupa pengetahuan dan informasi (Abdurrohaman, 1999). Berdasarkan pernyataan tersebut bahwa informasi yang didapatkan dalam proses belajar ialah hasil dari proses pembelajaran siswa. Belajar merupakan usaha sesorang dalam memperoleh suatu informasi maupun pengetahuan untuk dapat digunakan dalam menyelesaiakan permasalah yang dihadapi. Semakin banyak 
informasi yang didapat maka dapat membantu peserta didik dalam menyelesaikan tes hasil belajarnya.

\section{METODE PENELITIAN}

Metode yang digunakan dalam penelitian ini adalah metode survey kausal dengan teknik analisis jalur yang menguji pengaruh langsung dan tidak langsung dari setiap variabel.

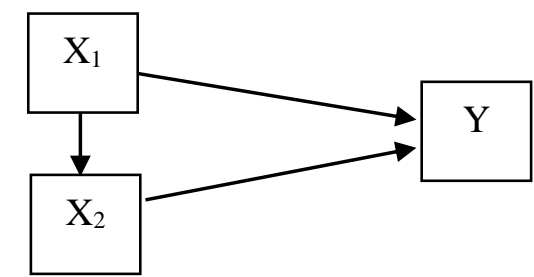

Gambar 1. Analisis Jalur Penelitian

Gambar di atas menunjukan variabel yang diamati dan dianalisis yaitu self efficacy $\left(\mathrm{X}_{1}\right)$ serta motivasi belajar $\left(\mathrm{X}_{2}\right)$ dan hasil belajar matematika (Y). Tujuan penelitian ini adalah mengetahui sejauh mana pengaruh self efficacy dan motivasi belajar terhadap hasil belajar matematika siswa di masa pandemi COVID-19.

Teknik pengumpulan data yang dilakukan yaitu menggunakan angket dengan skala likert untuk mengukur self efficacy dan motivasi belajar siswa melalui google form dan dokumen dari hasil belajar matematika siswa di ujian PAS semester ganjil 2020/2021. Populasi dalam penelitian yaitu siswa kelas IX MTs Al-Khairiyah Mampang Prapatan yang terdaftar pada tahun ajaran 2020/2021 yaitu sebanyak 158 siswa serta besarnya sampel menggunakan rumus Slovin (Sukardi, 2003) sehingga sampel dalam penelitian ini berjumlah 113 siswa. Analisis data menggunakan analisis korelasi bivariate dengan SPSS.

Tabel 1. Deskriptif Sampel

\begin{tabular}{cccc}
\hline \multirow{2}{*}{ Kelas } & \multirow{2}{*}{ Jumlah } & \multicolumn{2}{c}{ Gender } \\
\cline { 3 - 4 } & & Laki-laki & Perempuan \\
\hline IX A & 25 & 13 & 12 \\
IX B & 23 & 10 & 13 \\
IX C & 23 & 10 & 13 \\
IX D & 25 & 16 & 9 \\
IX E & 17 & 9 & 8 \\
\hline
\end{tabular}

\section{HASIL DAN PEMBAHASAN}

Data yang didapat dalam penelitian ini merupakan hasil dari pengisian angket di formulir google form kepada siswa kelas IX MTs Al-Khairiyah Mampang Prapatan yang terdiri dari sampel 113 siswa. Selanjutnya ditampilkan dalam tabel 2 matriks korelasi.

Tabel 2 menunjukan bahwa tingkat korelasi self efficacy dengan motivasi belajar yaitu sebesar 0,55. Sementara korelasi self efficacy dengan hasil belajar yaitu 0,75, dan korelasi motivasi belajar dengan hasil belajar yaitu 0,66. 
Tabel 2. Matriks Koefisien Korelasi

\begin{tabular}{cccc}
\hline Variabel & $\mathrm{X}_{1}$ & $\mathrm{X}_{2}$ & $\mathrm{Y}$ \\
\hline $\mathrm{X}_{1}$ & 1,00 & 0,55 & 0,75 \\
$\mathrm{X}_{2}$ & & 1,00 & 0,66 \\
$\mathrm{Y}$ & & & 1,00 \\
\hline
\end{tabular}

\section{Pengaruh Self Efficacy terhadap Hasil Belajar Matematika}

Sebelum melakukan uji hipotesis data terlebih dahulu uji normalitas galat taksiran antara self efficacy dan hasil belajar matematika dengan analisis regresi linear sederhana. Hasil analisi regresi linear dapat terlihat pada berikut.

Tabel 3. Analisis Regresi Linear Sederhana

\begin{tabular}{lc}
\hline \multicolumn{1}{c}{ Variabel } & Koefisien regresi \\
\hline Konstan & 27,888 \\
Self efficacy & 0,736 \\
\hline
\end{tabular}

Berdasarkan tabel tersebut persamaan regresi linear dalam memperkirakan hasil belajar matematika siswa dapat dipengaruhi self efficacy yaitu:

$$
Y=27,888+0,736 X_{1}
$$

Hal ini menunjukan bahwa setiap kenaikan nilai self efficacy maka akan berdampak pada penambahan 0,736 hasil belajar matematika pada kondisi awal 27,888. Oleh karena itu self efficacy berpengaruh positif terhadap hasil belajar matematika. Selanjutnya uji hipotesis dengan analisi jalur. Hipotesis awal penelitian ini adalah $\mathrm{H}_{0}: \beta_{31} \leq 0$ dan $\mathrm{H}_{1}: \beta_{31}>0$, dengan keputusan tolak $\mathrm{H}_{0}$ jika $t_{\text {hitung }}>t_{\text {tabel. }}$. Tabel 4 menunjukan hasil perhitungan analisi jalur.

Tabel 4. Analisis Jalur $\mathrm{X}_{1}$ terhadap $\mathrm{Y}$

\begin{tabular}{ccccc}
\hline \multirow{2}{*}{ Pengaruh } & \multirow{2}{*}{ Koefisien Jalur } & \multirow{2}{*}{$t_{\text {hitung }}$} & \multicolumn{2}{c}{$t_{\text {tabel }}$} \\
\cline { 3 - 5 } & & $\alpha=0,01$ & $\alpha=0,05$ \\
\hline $\mathrm{X}_{1}$ terhadap $\mathrm{Y}$ & 0,565 & $11,335 * *$ & 2,36 & 1,98 \\
\hline *** koefisien jalur sangat signifikan & $(11,335>2,36$ dengan & $\alpha=0,01)$
\end{tabular}

Berdasarkan perhitungan analisi jalur bahwa nilai koefisien jalur sebesar 0,565 dan nilai $t_{\text {hitung }}=11,335$ lebih besar dari tabel dengan $\alpha=0,01$ sebesar 2,36 dan $\alpha=0,05$ sebesar 1,98 , sehingga tolak $\mathrm{H}_{0}$ dan terima $\mathrm{H}_{1}$. Hal ini menunjukan bahwa self efficacy berpengaruh langsung positif terhadap hasil belajar matematika.

Hasil penelitian menunjukan bahwa self efficacy memberikan pengaruh positif terhadap hasil belajar siswa. Sehingga dengan meningkatnya self efficacy akan meningkat pula hasil belajar siswa. Hal ini sejalan dengan penelitian yang dilakukan oleh terdahulu bahwa menunjukan self efficacy berpengaruh positif terhadap hasil belajar (Suryani dkk., 2020; Wahdaniah dkk., 2017). Dikuatkan dengan penelitian Monika \& Adman (2017) bahwa efikasi diri mempengaruhi hasil belajar siswa.

Meningkatnya hasil belajar matematika dipengaruhi salah satunya oleh self efficacy. Untuk itu menjadi keharusnya bagi seorang pendidik untuk belajar cara meningkatkan self efficacy siswa dalam belajar. Beberapa cara dapat 
meningkatkan self efficacy diantaranya keberhasilan yang pernah dialami dapat meningkatkan keyakinan diri. Pengalaman orang lain dapat meningkatkan keyakinan diri seseorang, untuk itu seorang pendidikan perlu memberikan informasi mengenai keberhasilan orang lain sebagai sumber penyemangat dalam belajar. Selain itu arahan, nasihat serta bimbingan dapat meningkatkan keyakinan diri seseorang dalam mencapai keberhasilan.

\section{Pengaruh Motivasi Belajar terhadap Hasil Belajar Matematika}

Uji normalitas galat taksiran antara motivasi belajar dan hasil belajar matematika dengan analisis regresi linear sederhana. Hasil analisisnya pada Tabel 5.

Tabel 5. Analisis Regresi Linear Sederhana

\begin{tabular}{lc}
\hline \multicolumn{1}{c}{ Variabel } & Koefisien regresi \\
\hline Konstan & 36,944 \\
Motivasi Belajar & 0,650 \\
\hline
\end{tabular}

Berdasarkan Tabel 5, persamaan regresi linear dalam memperkirakan hasil belajar matematika siswa dapat dipengaruhi motivasi belajar yaitu:

$$
Y=36,944+0,650 X_{2}
$$

Hal ini menunjukan bahwa setiap kenaikan nilai motivasi belajar maka akan berdampak pada penambahan 0,650 hasil belajar matematika pada kondisi awal 36,944. Oleh karena itu motivasi belajar berpengaruh positif terhadap hasil belajar matematika. Selanjutnya uji hipotesis dengan analisi jalur. Hipotesis awal penelitian ini adalah $\mathrm{H}_{0}: \beta_{32} \leq 0$ dan $\mathrm{H}_{1}: \beta_{32}>0$, dengan keputusan tolak $\mathrm{H}_{0}$ jika $t_{\text {hitung }}>t_{\text {tabel. }}$. Tabel 6 menunjukan hasil perhitungan analisi jalur.

Tabel 6. Analisis Jalur $\mathrm{X}_{2}$ terhadap $\mathrm{Y}$

\begin{tabular}{ccccc}
\hline \multirow{2}{*}{ Pengaruh } & \multirow{2}{*}{ Koefisien Jalur } & \multirow{2}{*}{$t_{\text {hitung }}$} & \multicolumn{2}{c}{$t_{\text {tabel }}$} \\
\cline { 3 - 5 } & & $\alpha=0,01$ & $\alpha=0,05$ \\
\hline $\mathrm{X}_{2}$ terhadap $\mathrm{Y}$ & 0,434 & $8,71 * *$ & 2,36 & 1,98 \\
\hline **koefisien jalur sangat signifikan & $(8,71>2,36$ dengan & $\alpha=0,01)$
\end{tabular}

Berdasarkan perhitungan analisi jalur bahwa nilai koefisien jalur sebesar 0,434 dan nilai $t_{\text {hitung }}=8,71$ lebih besar dari tabel dengan $\alpha=0,01$ sebesar 2,36 dan $\alpha=0,05$ sebesar 1,98, sehingga tolak $\mathrm{H}_{0}$ dan terima $\mathrm{H}_{1}$. Hal ini menunjukan bahwa motivasi belajar berpengaruh langsung terhadap hasil belajar matematika.

Selain self efficacy, motivasi dalam belajar juga berpengaruh positif terhadap hasil belajar siswa. Motivasi yang tinggi dalam diri siswa akan memberikan daya dorong dalam melakukan pembelajaran, hal ini sesuai dengan penelitian Singh dkk. (2002) bahwa motivasi serta hasil akademik memiliki keterkaitan satu sama lain. Dikuatkan dengan penelitian Adirestuty (2019) bahwa motivasi belajar memiliki korelasi positif terhadap hasil belajar siswa.

\section{Pengaruh Self Efficacy terhadap Motivasi Belajar}

Uji normalitas galat taksiran antara self efficacy dan motivasi belajar menggunakan analisis regresi linear sederhana. Hasil analisinya pada Tabel 7. 
Tabel 7. Analisis Regresi Linear Sederhana

\begin{tabular}{cc}
\hline Variabel & Koefisien regresi \\
\hline Konstan & 47,245 \\
Self efficacy & 0,548 \\
\hline
\end{tabular}

Berdasarkan tabel tersebut persamaan regresi linear dalam memperkirakan motivasi belajar siswa dapat dipengaruhi self efficacy yaitu:

$$
X_{2}=47,245+0,548 X_{1}
$$

Hal ini menunjukan bahwa setiap kenaikan nilai self efficacy akan berdampak pada penambahan 0,548 motivasi belajar pada kondisi awal 47,245. Oleh karena itu self efficacy berpengaruh positif terhadap motivasi belajar. Selanjutnya uji hipotesis dengan analisi jalur. Hipotesis awal penelitian ini adalah $\mathrm{H}_{0}: \beta_{21} \leq 0$ dan $\mathrm{H}_{1}: \beta_{21}>0$, dengan keputusan tolak $\mathrm{H}_{0}$ jika $t_{\text {hitung }}>t_{\text {tabel }}$. Tabel 8 menunjukan hasil perhitungan analisi jalur.

Tabel 8. Analisis Jalur $\mathrm{X}_{1}$ terhadap $\mathrm{X}_{2}$

\begin{tabular}{ccccc}
\hline \multirow{2}{*}{ Pengaruh } & \multirow{2}{*}{ Koefisien Jalur } & \multirow{2}{*}{$\mathrm{t}_{\text {hitung }}$} & \multicolumn{2}{c}{$\mathrm{t}_{\text {tabel }}$} \\
\cline { 3 - 5 } & & & $\alpha=0,01$ & $\alpha=0,05$ \\
\hline $\mathrm{X}_{1}$ terhadap $\mathrm{X}_{2}$ & 0,305 & $6,592 * *$ & 2,36 & 1,98 \\
\hline$* *$ koefisien jalur sangat signifikan & $(6,592>2,36$ & dengan $\alpha=0,01)$
\end{tabular}

Berdasarkan perhitungan analisis jalur bahwa nilai koefisien jalur sebesar 0,305 dan nilai $t_{\text {hitung }}=6,592$ lebih besar dari $t_{\text {tabel }}$ dengan $\alpha=0,01$ sebesar 2,36 dan $\alpha=0,05$ sebesar 1,98 , sehingga tolak $\mathrm{H}_{0}$ dan terima $\mathrm{H}_{1}$. Hal ini menunjukan bahwa self efficacy berpengaruh langsung terhadap motivasi belajar.

Berdasarkan hasil penelitian menunjukan bahwa self efficacy berpengaruh langsung terhadap motivasi dalam belajar. Penelitian yang dilakukan Zega (2020) bahwa hubungan antara self efficacy dengan motivasi belajar diperoleh 51,20\% artinya lebih dari 50\% motivasi belajar dipengaruhi oleh self efficacy. Selain itu hasil penelitian Sucitno dkk. (2020) menyatakan bahwa terdapat pengaruh antara self efficacy secara signifikan terhadap motivasi belajar.

\section{SIMPULAN}

Hasil penelitian ini memperkuat landasan teori mengenai self efficacy serta motivasi dalam belajar yang berngaruh terhadap hasil pembelajaran matematika di MTs Al-Khairiyah Mampang Prapatan. Meskipun penelitian ini khusus dilakukan pada pelajaran matematika karena dianggap sebagai pelajaran utama dalam proses belajar. Berdasarkan analisis data maka penelitian ini memberikan hasil self efficacy dan motivasi dalam belajar berpengaruh positif terhadap hasil pembelajaran matematika.

Siswa dengan kepercayaan diri yang tinggi dalam belajar akan lebih menunjukan kegigihan dalam mempelajari materi pelajaran meskipun dalam kondisi pandemi yang membuat siswa lebih banyak belajar melalui daring. Dari keyakinan diri yang tinggi akan menimbulkan motivasi belajar tinggi pula. Saat 
menghadapi soal matematika yang lebih menantang, siswa dengan self efficacy dan motivasi yang cukup tinggi akan gigih dan pantang menyerah dalam memecahkan masalah tersebut, bila dibandingkan dengan siswa yang self efficacy dan motivasi belajarnya rendah. Tentunya akan berpengaruh kepada hasil dari proses belajar matematika siswa tersebut.

Penelitian ini tentunya memiliki keterbatasan yang perlu dikembangkan dalam penelitian lanjutan. Pembatasan variabel yang diukur yaitu self efficacy, motivasi belajar terhadap hasil belajar tentunya bukan faktor utama. Terlebih saat pembelajaran online dengan kemungkinan besar siswa dapat mencari jawaban melalui internet dalam menyelesaikan tugas-tugas maupun ujian.

\section{REFERENSI}

Abdurrohaman, M. (1999). Pendidikan Bagi Anak Berkesulitan Belajar. Jakarta: Rineka Cipta.

Adirestuty, F. (2019). Pengaruh Self-Efficacy Guru dan Kreativitas Guru Terhadap Motivasi Belajar Siswa dan Implikasinya Terhadap Prestasi Belajar Pada Mata Pelajaran Ekonomi. Jurnal Wahana Pendidikan, 4(1), 54-67.

Bandura, A. (1999). Social cognitive theory: An agentic perspective1. Asian Journal of Social Psychology, 21-41.

Friedman, I. A. (2003). Self-efficacy and burnout in teaching: The importance of interpersonal-relations efficacy. Social Psychology of Education, 6(3), 191215.

Hapsari, S. (2005). Bimbingan dan Konseling SMA Untuk Kelas XII. Jakarta: PT Grasindo.

Hendrastomo, G. (2008). Dilema dan tantangan pembelajaran e-learning. Majalah Ilmiah Pembelajaran, 4(1), 32-35.

Kizilbash, A. H., Vanderploeg, R. D., \& Curtiss, G. (2002). The effects of depression and anxiety on memory performance. Archives of Clinical Neuropsychology, 17(1), 57-67. https://doi.org/10.1016/S08876177(00)00101-3

Li, J., Yang, Z., Qiu, H., Wang, Y., Jian, L., Ji, J., \& Li, K. (2020). Anxiety and depression among general population in China at the peak of the COVID-19 epidemic. World Psychiatry, 19(2), 249-250. https://doi.org/10.1002/wps.20758

Locke, E. A. (1997). Self-efficacy: The exercise of control. Personnel psychology, 50(3), 801-804.

Monika, M., \& Adman, A. (2017). Peran efikasi diri dan motivasi belajar dalam meningkatkan hasil belajar siswa sekolah menengah kejuruan. Jurnal Pendidikan Manajemen Perkantoran, 1(1), 110-117. https://doi.org/10.17509/jpm.v2i2.8111

Dimyati., \& Mudjiono. (1994). Belajar dan Pembelajaran. Jakarta: Depdikbud.

Nashr. (2004). Peranan Motivasi dan Kemampuan awal dalam kegiatan pembelajaran. Jakarta: Delia Press.

Ning, B. (2020). Discipline, motivation, and achievement in mathematics learning: An exploration in Shanghai. School Psychology International, 41(6), 595-611. https://doi.org/10.1177/0143034320961465 
Niu, H. J. (2010). Investigating the effects of self-efficacy on foodservice industry employees' career commitment. International Journal of Hospitality Management, 29(4), 743-750.

Santrock, J. W. (2009). Psikologi Pendidikan. Jakarta: Salemba Humanika.

Sardiman, A. M. (2000). Interaksi dan Motivasi Belajar Mengajar. Jakarta: Grafindo Persada.

Singh, K., Granville, M., \& Dika, S. (2002). Mathematics and science achievement: Effects of motivation, interest, and academic engagement. Journal of Educational Research, 95(6), 323-332. https://doi.org/10.1080/00220670209596607

Sucitno, F., Sumarna, N., \& Silondae, D. P. (2020). Pengaruh Self-Efficacy Terhadap Motivasi Belajar Pada Siswa. Jurnal Sublimapsi, 1(3), 114-119.

Sudjana, N. (2005). Metode Statistika. Bandung: Tarsito.

Sukardi. (2003). Metodologi Penelitian Pendidikan. Jakarta: PT. Bumi Aksara.

Sundari, F. (2017). Peran Guru Sebagai Pembelajar dalam Memotivasi Peserta Didik Usia SD. Prosiding Diskusi Panel Nasional Pendidikan, 60-76.

Suprihatiningrum, J. (2013). Strategi Pembelajaran. Yogyakarta: Ar-Ruzz Media.

Suryani, L., Seto, S. B., \& Bantas, M. G. D. (2020). Hubungan Efikasi Diri dan Motivasi Belajar Terhadap Hasil Belajar Berbasis E-Learning pada Mahasiswa Program Studi Pendidikan Matematika Universitas Flores. Jurnal Kependidikan: Jurnal Hasil Penelitian Dan Kajian Kepustakaan Di Bidang Pendidikan, Pengajaran Dan Pembelajaran, 6(2), 275. https://doi.org/10.33394/jk.v6i2.2609

Tambunan, H. (2018). The Dominant Factor of Teacher's Role as a Motivator of Students' Interest and Motivation in Mathematics Achievement. International Education Studies, 11(4), 144-151. https://doi.org/10.5539/ies.v11n4p144

Tseng, S. C., \& Tsai, C. C. (2010). Taiwan college students' self-efficacy and motivation of learning in online peer assessment environments. Internet and Higher Education, 13(3), 164-169. https://doi.org/10.1016/j.iheduc.2010.01.001

UNESCO. (2020). Framework for reopening schools [PDF File]. Tersedia: https://www.unicef.org/media/68366/file/Framework-for-reopening-schools2020.pdf

Wahdaniah, W., Rahman, U., \& Sulateri, S. (2017). Pengaruh Efikasi Diri, Harga Diri Dan Motivasi Terhadap Hasil Belajar Matematika Peserta Didik Kelas X Sma Negeri 1 Bulupoddo Kab. Sinjai. MaPan, 5(1), 68-81. https://doi.org/10.24252/mapan.2017v5n1a5

Wahyuningtyas, N., \& Febrianingsih, L. (2018). Pengaruh Self Efficacy Dan Motivasi Terhadap Hasil Belajar Matematika Siswa. JP2M (Jurnal Pendidikan Dan Pembelajaran Matematika), 4(1), 38-46. https://doi.org/10.29100/jp2m.v4i1.1777

Wigfield, A., Klauda, S. L., \& Cambria, J. (2011). Influences on the development of academic self-regulatory processes. Handbook of self-regulation of learning and performance, 33-48.

Yang, X., Zhang, M., Kong, L., Wang, Q., \& Hong, J.-C. (2020). The Effects of Scientific Self-efficacy and Cognitive Anxiety on Science Engagement with "Question-Observation-Doing-Explanation" Model during Schools 
11 | Sari, Yana \& Wulandari, Pengaruh Self Efficacy dan Motivasi Belajar ...

Disruption in COVID-19 Pandemic. 1-28. https://doi.org/10.21203/rs.3.rs40814/v1

Yunianti, E. (2016). Pengaruh Model Pembelajaran Dan Self-Efficacy Terhadap Hasil Belajar Matematika Siswa SMA Negeri 1 Parigi. E-JurnalMitra Sains, $1,92-100$.

Yusuf, M. (2011). The impact of self-efficacy, achievement motivation, and selfregulated learning strategies on students' academic achievement. Procedia Social and Behavioral Sciences, 15, 2623-2626. https://doi.org/10.1016/j.sbspro.2011.04.158

Zega, Y. (2020). Hubungan Self Efficacy terhadap Motivasi Belajar. Didaktik, 14(1), 2410-2416. 